\title{
Review Essay: Reading the Victorian Underworld
}

Anthony E. Simpson; W. T. Stead, The Maiden Tribute of Modern Babylon: The Report of the Secret Commission | Anthony E. Simpson, Witnesses to the Scaffold: English Literary Figures as Observers of Public Executions: Pierce Egan, Thackeray, Dickens, Alexander Smith, G.A. Sala, Orwell | Mark Freeman \& Gillian Nelson, Vicarious Vagrants: Incognito Social Explorers and the Homeless in England, 1860-1910

\section{Rosalind Crone}

\section{(2) OpenEdition} Journals

Electronic version

URL: https://journals.openedition.org/chs/1148

DOI: $10.4000 /$ chs. 1148

ISSN: 1663-4837

\section{Publisher}

Librairie Droz

\section{Printed version}

Date of publication: 1 May 2010

Number of pages: 95-101

ISBN: 978-2-600-01425-0

ISSN: $1422-0857$

Electronic reference 


\title{
Review Essay: Reading the Victorian Underworld
}

\author{
Rosalind Crone
}

Anthony E. Simpson; W. T. Stead, The Maiden Tribute of Modern Babylon: The Report of the Secret Commission, Lambertville, NJ, The True Bill Press, 2007, 270 pp., ISBN, 978-0-9791116-0-0.

Anthony E. Simpson, Witnesses to the Scaffold: English Literary Figures as Observers of Public Executions: Pierce Egan, Thackeray, Dickens, Alexander Smith, G.A. Sala, Orwell, Lambertville, NJ, The True Bill Press, 2008, 230 pp., ISBN, 978-0-9791116-1-7.

Mark Freeman \& Gillian Nelson, Vicarious Vagrants : Incognito Social Explorers and the Homeless in England, 1860-1910, Lambertville, NJ, The True Bill Press, 2008, 327 pp., ISBN, 978-0-9791116-2-4.

At the end of the first decade of the twenty-first century, there is no denying that new digital technologies have dramatically reshaped the way we conduct research, not least in the reproduction of large numbers of primary sources online, including many that were previously difficult for scholars to access. An unprecedented range of key resources in the history of nineteenth-century crime can be viewed by almost anyone, anywhere, at any time. Furthermore, advances in scanning technology have meant that the primary sources which appear on our screens are ever closer to the originals that we find in the archives. Yet there is a flipside to this movement. Rightly or wrongly, those wishing to publish anthologies of sources in printed book form have found themselves under increasing pressure to justify the use of this traditional method of presentation, first to publishers and second, and more importantly, to readers or purchasers. And this particularly rings true when the reproduction of key sources is purely textual, for example, when the sources have been literally 'reproduced' so that surrounding literary and decorative features have been eliminated.

The bar has thus been set rather high for the three volumes under review here: W.T. Stead's The Maiden Tribute of Modern Babylon (2007) and Witnesses to the Scaffold: English literary figures as observers of public executions (2008), both edited by Anthony E. Simpson, and Vicarious Vagrants: Incognito social explorers and the homeless in England, 1860-1910 (2008), edited by Mark Freeman and Gillian Nelson. On the face of it, the publication of these anthologies makes sense in terms of their marketability as the subject matter is especially appealing. For the most part, the set focuses on the nineteenth-century underworld, mainly in London, each volume carving out a particular theme, respectively: prostitution and the lucrative market in the forced seduction of young virgins; execution and its attendant 
crowd; and the homeless who sheltered at night in the casual wards of the Victorian workhouses. At the same time, however, all the primary sources featured in the three volumes are well-known by nineteenth-century scholars and, with only a few exceptions from the last volume, Vicarious Vagrants, all are accessible online, some as scanned copies of the originals. In such circumstances, these books need to demonstrate a scholarly purpose beyond satisfying the often fickle interests of the general public.

Arguably, some justification can be found in the extensive editorial introductions accompanying each volume which seek to place the sources within their historical context and provide a rationale for the selection of the texts and their presentation. In particular, the wide socio-historical surveys of prostitution, execution and vagrancy highlight the usefulness of these books for undergraduates. Yet, at the same time, I think the editors could have been even more ambitious, and through their choice and positioning of these primary sources offer a challenge or at least a fresh contribution to the existing historiography on crime, society and culture in nineteenth-century England.

A clear introductory essay by Simpson accompanies The Maiden Tribute, the famous series of articles by W.T. Stead, published in his Pall Mall Gazette in July 1885 , which described the sale of innocent virgins mostly aged between thirteen and sixteen to wealthy, lecherous punters by brothel keepers. Simpson firmly places Stead's endeavours within the context of debates about prostitution and its legality in the nineteenth century. He highlights its relationship to the Criminal Law Amendment Act of 1885 which, as a Bill, had stalled in the legislative process at Westminster during the summer of that year. Although a number of historians have argued that Stead's articles were timely, as the sensation created not only helped to ensure the passage of the 1885 Act but also convinced Parliament to raise the age of sexual consent for girls from thirteen to sixteen and increase the powers of prosecution over streetwalkers and brothel keepers, Simpson cautions us not to overestimate the significance of either the articles or the legislation. In addition, Simpson exposes the key flaws within Stead's analysis of the problem of sexual abuse, namely his insistence upon the innocence of the so-called victims and the way in which he glossed over evidence of sexual relations with girls under thirteen, both of which were related to Stead's anxiety to provide a coherent narrative of class exploitation but which totally ignored more common patterns of sexual abuse in society. These are salient (if not new) criticisms of Stead's journalism ${ }^{1}$. However, their presentation in this essay ultimately marginalises the importance of The Maiden Tribute, especially as Simpson does not extend his analysis further to suggest other reasons for the articles' significance, prompting the reader to question the rationale behind this publication.

Similarly, the editorial material featured in Witnesses to the Scaffold is extensive. The long introductory essay provides a comprehensive overview of the place of execution within the British criminal justice system during the eighteenth and nineteenth centuries. It also sets out the fundamental concern of the book designed to link together the selected extracts: why do large numbers of people watch public executions? Simpson does not provide a direct answer, but instead presents a series

Most notably, by Walkowitz (1992, pp. 81-134), but also, for example: Devereux (2000); Gorham (1978); Phillips (2000); Robson (1978); Pearson (1972). 
of accounts from British literary figures of the nineteenth and early twentieth centuries to illustrate the diversity in depictions of the event and its spectators. For the most part, the sources are directly linked to the historical trajectory outlined in the introduction (though each is also accompanied by a separate essay on the author and his work as well as the grounds for the execution). Thus we move from Pierce Egan's admiration for the dignified manner by which the murderer John Thurtell went to his death, as representative of a more traditional way of viewing execution which was receding with the rationalisation and finally dismantlement of the Bloody Code during the 1820s and 1830s, to the general personal disgust felt in watching felons hang accompanied by competing illustrations of the execution crowd provided by William Makepeace Thackeray, Charles Dickens, Alexander Smith and George Augustus Sala during the 1840s and 1850s, a period in which only murderers were executed and debates about the wisdom of doing this publicly were rife. Within this narrative, the final extract, George Orwell's 'A Hanging', a reflective piece on an execution in Burma during the 1920s, seems to be very much out of place as well as inadequately contextualised.

If we set the Orwell piece to one side and focus upon the nineteenth-century material, I am somewhat surprised by the way in which these literary accounts have been positioned by the editorial notes. Simpson is quite right to draw our attention to the biases contained within each, but his use of reports of executions in The Times as a yardstick by which to measure the authenticity of these writers' accounts is problematic. Descriptions of scaffold crowds provided by newspapers were equally subjective and often conformed to a specific agenda. As a result, reports on the same event often differed between newspapers. And so while The Times drew readers' attention to the rowdy behaviour of the crowd present at the execution of Frederick and Maria Manning on 13 November 1849, as Dickens did in his letter to the editor of that newspaper (reproduced by Simpson), Lloyd's Weekly News, a paper distributed on Sundays with a circulation of around 50,000 and a growing working and lower-middle class readership, stated that by the morning the revellers had exhausted themselves and only orderly spectators remained to watch the deaths of the prisoners ${ }^{2}$.

At the same time, the Mannings' execution crowd also featured in text and image on broadsides sold to its members at the foot of the scaffold as well as to people in the streets of London and provincial towns. Like newspaper reporters, broadside printers also offered competing accounts of the composition and behaviour of the crowd $^{3}$. These were crafted before the execution even took place to ensure the broadsides would be ready for immediate sale, thus their accuracy as a record of the event is limited. Similarly, the woodcut of the gallows with attendant crowd accompanying the broadside text was typically identical to every other execution broadside distributed by the particular printer ${ }^{4}$. But such repetition and lack of precision does not challenge the authenticity of these descriptions. Execution broadsides provided a representation of the event, in the same way that newspapers and the literary

The Times (13 Nov. 1849, p. 4); Lloyd's Weekly News (18 Nov. 1849, pp. 2-3).

For example, see Execution of Frederick George and Maria Manning (Ryle \& Co., Seven Dials, London, 1849), Oxford, Bodleian Library (Bod.), John Johnson Collection (JJ), Murder and Execution Broadsides, Fol. 6 (large).

4 For a detailed discussion of broadside imagery, see Gatrell (1994, pp. 156-196). 
accounts featured in the volumes did. Moreover, none of these genres should be regarded in isolation from each other. Broadsides influenced newspaper reports on executions, as journalists adopted a similar format in the illustration of the days' events and often used the same stock euphemisms to describe the death of the felon, probably because these were set narratives with which readers had become comfortable. Most of all, the phenomenal sales of broadsides (around 2,500,000 for the execution of the Mannings) and the increase in circulation experienced by newspaper editors for issues featuring executions highlight the great desire of the Victorians of all classes to read about these events ${ }^{5}$. This great appeal may well have provided the primary impetus for the four nineteenth-century journalists featured in Witnesses to the Scaffold (Egan, Thackeray, Dickens and Sala) to write their articles. In other words, in order to fully understand the nineteenth-century execution crowd, and the even the context of the sources that are reproduced in the volume, Witnesses to the Scaffold needs to be studied alongside a wider range of alternative execution accounts, especially those directed at different audiences.

The selection of sources for the third volume, Vicarious Vagrants, is similarly tightly focused. All are either articles published in newspapers or popular journals or short books written by middle-class men and women who, between 1860 and 1910 , went in disguise among the homeless in order to expose the conditions in which they lived. Although I was a little disappointed not to find an extract from the book after which this collection was named, Walter Thomas Cranfield's A Vicarious Vagabond (1910) (apart from his photograph, that is), those sources that do feature in this volume are well chosen. In particular, the editors use these to demonstrate how concern about vagrancy in England shifted in important ways over three distinct periods. For example, James Greenwood's 'A Night in a Workhouse' and J.H. Stallard's The Female Casual and her Lodging, both published in 1866, are representative of fears about the worsening problem of vagrancy and anxiety about conditions within workhouses at a time when poor relief expenditure was increasing. Debates about the social residuum prompted another set of social explorations during the 1880s. And, at the turn of the twentieth century, large-scale unemployment combined with the issue of 'national efficiency' again informed the representations of casual wards of workhouses by Mary Higgs, Everard Wyrall and George Z. Edwards. The specific concentration on the stories of those who lived for short periods among the homeless is intense. Certainly for these defined periods of social concern to be borne out, these sources need to be supplemented by other evidence, for example Parliamentary Papers, newspaper reports and criminal court records. But, at the same time, the volume dovetails well with other recent publications on this theme, notably Seth Koven's Slumming (2004) and Ellen Ross's Slum Travellers (2007) ${ }^{6}$.

Yet Freeman and Nelson do provide further valuable justification for the reproduction of extracts from within this peculiar genre: that this early undercover research helped to lay the foundations for modern sociological and anthropological studies. Incognito visits to various underworld, controversial or 'forgotten' locations continue today, pursued by both members of the academy and journalists. The distinction between the research conducted by each group is particularly evident in

Broadside sales based on Henry Mayhew's estimate: see Mayhew (1861, I, p. 284).

6 Koven, (2004, especially pp. 25-87); Ross (2007). Vicarious Vagrants also reads like a rather concentrated version of Keating's 1976 collection. 
the way in which they record their experiences, the career social scientist eager to enhance the authority of their work by using a thematic structure, while the reporter employs a dramatic narrative to engage their reader. But one hundred years ago, such a distinction did not exist: although they told the story of their endeavours, and would today be regarded as 'amateurs', the 'vicarious vagrants produced social documents that both reflected and shaped the concerns of legislators and philanthropists in this key period of social and political change"7.

While it is a convincing analysis, I cannot help but feel that Freeman and Nelson, like Simpson in Witnesses to the Scaffold and The Maiden Tribute, have played down the role of the audience in the production and significance of these texts. In other words, each volume in this series regards the text as the end point: in their editorial notes, Simpson, Freeman and Nelson look back from the position of the text to see what it says about the theme in question. In other words, they see the authors of every text as responding to the state of prostitution, execution or vagrancy in nineteenth-century England. But each text was written with readers in mind. Authors intended their representations of these issues would have some impact, though they could never accurately predict what that might be. Thus, if, instead, we view the text as the starting point, and consider its reception in the nineteenth century, then these volumes could, collectively, challenge some long-held assumptions about Victorian society and suggest some new pathways for scholarship.

This potential is most evident in the first volume, The Maiden Tribute. Simpson has not only provided us with the series of articles which comprised this famous exposé, but he has also included related material published in the Pall Mall Gazette contemporaneously to highlight the extent of the scandal provoked by Stead's stories. Debate about the appropriateness of the sale and consumption of this rather risqué material raged at all levels of society. While mainstream newsagents such as W.H. Smith refused to sell the newspaper, a discrete group of angry readers withdrew their patronage and Parliament attempted to impose an injunction on the publication, at the same time insatiable public demand encouraged street sellers to raise the price and increase their profit margins, newspaper employees found themselves besieged at their offices in Northumberland Street by a large crowd anxious to obtain the latest instalment, and notable men and women wrote firm letters of support to Stead. In the main, both sides of the debate couched their arguments within the language of respectability: on the one had, it was asserted that Stead's articles were obscene and thus offensive to a respectable readership; but on the other hand, the exposé was deemed necessary to safeguard respectability, including that of the victims, of the perpetrators and of wider society.

Moreover, many historians have demonstrated how W.T. Stead and 'The Maiden Tribute' helped to promote the emergence of New Journalism during the last third of the nineteenth century by using sensationalism in order to encourage the democratisation of news and, by extension, society ${ }^{8}$. While, on the surface, these aims sound noble, in the main New Journalism signalled the shift away from Parliamentary and political intelligence in newspapers towards a focus on sport, gossip, crime and sex. As Aled Jones has argued, the period of the New Journalism in England was largely defined by a decreasing concern with respectability matched with a new pursuit of

Freeman, Nelson (2008, p. 47).

Boston, (1988); Campbell (2003); Hampton (2004). 
profit by reporters, editors and proprietors ${ }^{9}$. However, although the term 'New Journalism' was first coined in the 1880s, arguably the style of reporting was not necessarily very novel. The Pall Mall Gazette, for instance, had been publishing journalistic exposés since its inception under the editorship of Frederick Greenwood in 1865, the prime example of which was James Greenwood's 'Night in a Workhouse', reproduced in Vicarious Vagrants, providing readers with a grimy and confronting account of life in the underworld ${ }^{10}$. And many scholars have drawn our attention to the roots of the New Journalism in the Sunday press formed during the 1840s and 1850 s, originally aimed at a working and lower-middle class readership and ultimately successful in incorporating popular traditions from the broadside trade; both publications have been mentioned above in relation to their coverage of crime and execution ${ }^{11}$.

Judith Walkowitz has suggested that the importance of the Pall Mall Gazette was its ability to extend popular news presentation to a more elite readership ${ }^{12}$. But we must not forget that the interest of the so-called 'respectable' classes in crime and low-life was already established in the first half of the nineteenth century, as evident in the extracts presented in Witnesses to the Scaffold. Even if these were reflective pieces, moral treatises even, on the legitimacy and utility of public execution, they were also composed with the view to pleasing audiences, for the most part affluent and respectable, hence the inclusion of very graphic details about the antics of the execution crowd as well as the manner in which the felon died. Thackeray, Dickens and Sala especially could be described as mid-nineteenth century flaneurs, urban explorers who wandered the streets of Victorian London casting a privileged gaze on those below in the social hierarchy while seeking good copy to thrill readers ${ }^{13}$. Similarly, respectable men and women who consumed these narratives consciously used the descriptions of vulgarity, rowdiness and violence to distance themselves from the crowd and from the perceived culture of the underclass. But their enjoyment of these tales also implicated these readers. The size of the execution crowd and its composition was much wider than those who physically attended the event. And if the incognito explorers became vicarious vagrants through participant observation, their large, non-professional readerships found another level of involvement in the thrilling digestion of the stories.

In sum, The Maiden Tribute, Witnesses to the Scaffold and Vicarious Vagrants demonstrate, if unintentionally, how the wide range of texts on the Victorian underworld produced for predominantly affluent audiences force us to reconsider demarcations in nineteenth-century society, especially those between the respectable and the unrespectable. The pervasiveness of narratives about low-life and crime at every level of society suggests that respectability, if dominant in Victorian culture, has been largely misunderstood.

Rosalind Crone

The Open University

R.H.Crone@open.ac.uk

Jones (1996, p. 137).

10 Diamond (1988).

11 Wiener (1988); Lee (1976, pp. 101; 128); Brown (1985 p. 31).

12 Walkowitz (1992 p. 84).

13 Walkowitz (1992, pp. 16-21); Nead (2000, pp. 67-73); Nord (1995, pp. 1-18). 


\section{REFERENCES}

Boston, R., W.T. Stead and democracy by journalism, in Wiener J. (ed.), Papers for the millions: the New Journalism in Britain, 1850s to 1914, New York, Greenwood, 1988.

Brown, L., Victorian news and newspapers, Oxford, Clarendon Press, 1985.

Campbell, K., W.E. Gladstone, W.T. Stead, Matthew Arnold and a New Journalism: cultural politics in the 1880s, Victorian Periodicals Review, 2003, 36, pp. 20-40.

Devereux, C., "The Maiden Tribute" and the rise of the white slave in the nineteenth century: the making of an imperial construct, Victorian Review, 2000, 26, pp. 1-23.

Diamond, B.I., A precursor of the New Journalism: Frederick Greenwood of the Pall Mall Gazette, in Wiener, J. (ed.), Papers for the millions : the New Journalism in Britain, 1850s to 1914, New York, Greenwood, 1988.

Jones, A., Powers of the press : newspapers, power and the public in nineteenth-century England, Aldershot, Scholar Press, 1996.

Gatrell, V.A.C., The hanging tree: execution and the English people, 1770-1868, Oxford, Oxford University Press, 1994.

Gorham, D., The "Maiden Tribute of Modern Babylon" re-examined: child prostitution and the idea of childhood in late-Victorian England, Victorian Studies, 1978, 21, pp. 353-379.

Hampton, M., Visions of the press in Britain, 1850-1950, Illinois, University of Illinois Press, 2004.

Keating P.J. (ed.), Into unknown England, 1866-1913: selections from the social explorers, Manchester, Manchester University Press, 1976.

Koven, S., Slumming : sexual and social politics in Victorian London, Princeton, NJ, Princeton University Press, 2004.

Lee, A.J., The origins of the popular press in England 1855-1914, London, Croom Helm, 1976.

Mayhew, H., London labour and the London poor, 4 vols., London, Woodfall, 1861.

Nead, L., Victorian Babylon : people, streets and images in nineteenth-century London, New Haven, Yale University Press, 2000.

Nord, D. E., Walking the Victorian streets : women, representation and the city, Ithaca, Cornell University Press, 1995.

Pearson, M., The age of consent: Victorian prostitution and its enemies, Newton Abbott, David and Charles, 1972.

Phillips, R., Imagined geographies and sexuality politics: the city, the country and the age of consent, in Shuttleton, D., Phillips, R., Watt, D. (eds), De-centring sexualities : politics and representations beyond the metropolis, London, Routledge, 2000.

Robson A., The significance of “The Maiden Tribute of Modern Babylon”, Victorian Periodicals Newsletter, 1978, 11, pp. 50-57.

Ross, E., Slum travellers: ladies and London poverty, 1860-1920, Berkeley, University of California Press, 2007.

Walkowitz, J. R., City of dreadful delight: narratives of sexual danger in late-Victorian London, Chicago, Chicago University Press, 1992.

Wiener, J. (ed.), Papers for the millions : the New Journalism in Britain, 1850s to 1914, New York, Greenwood, 1988.

Wiener, J., How new was the New Journalism, in Wiener, J. (ed.), Papers for the millions : the New Journalism in Britain, 1850s to 1914, New York, Greenwood, 1988. 